\title{
Groundcover Management Systems Influence Fungicide and Nitrate-N Concentrations in Leachate and Runoff from a New York Apple Orchard
}

\author{
Ian A. Merwin ${ }^{1}$ and John A. Ray ${ }^{2}$ \\ Department of Fruit and Vegetable Science, Cornell University, Ithaca, NY, 14853 \\ Tammo S. Steenhuis ${ }^{3}$ and Jan Boll ${ }^{4}$ \\ Department of Agricultural and Biological Engineering, Cornell University, Ithaca, NY, 14853 \\ Additional index words. pesticides, nonpoint-source pollution, environmental impacts, groundwater, Malus domestica , \\ preferential flow, macropore flow, benomyl (methyl-1-(butylcarbamoyl)-2-benzimidazole-carbamate)
}

\begin{abstract}
Commercial apple (Malus domestica Borkh.) orchards in the northeastern United States receive heavy pesticide inputs and are often located on well-drained soils near surface and groundwater resources. Nonpoint-source water pollution by agrichemicals has been monitored in agronomic crop systems and simulated using computer models and laboratory soil columns, but inadequately studied at field scale in orchards. We monitored the concentrations of agrichemical tracers, nitrate- $\mathbf{N}$, and benomyl fungicide in water samples from two apple orchards under mowed sodgrass (Mowed-Sod), shredded bark mulch (Bark-Mulch), preemergence residual herbicides (Resid-Herb), and postemergence herbicide (Post-Herb) groundcover management systems (GMSs). In one orchard, we evaluated subsurface spatial patterns and flow rates of a weakly adsorbed blue dye (pesticide analog) and potassium bromide (nitrate analog) under trees after six years of Post-Herb and Mowed-Sod treatments. Nitrate and pesticide tracers leached more rapidly and in higher concentrations under Post-Herb treatments, apparently via preferential macropore flowpaths such as root channels, soil cracks, and macrofauna burrows. At another orchard, we monitored subsurface leaching and surface runoff of benomyl and nitrate- $\mathrm{N}$ on a whole-field scale. Peak concentrations of benomyl (up to $29 \mathrm{mg}^{-1 i t e r}{ }^{-1}$ ) and nitrates (up to $20 \mathrm{mg} \cdot \mathrm{liter}^{-1}$ ) were observed in subsoil leachate under Resid-Herb plots during 1993. In 1994, nitrate concentrations were greater in leachate from all GMSs, with upper ranges from 48 to $66 \mathrm{mg} \cdot$ liter $^{-1}$, while benomyl concentrations were lower in all GMSs compared with the previous summer. In surface water runoff during 1993, the highest benomyl concentrations $\left(387 \mathrm{mg}\right.$ liter $^{-1}$ ) and most frequent outflows occurred in Resid-Herb plots. During 1994, benomyl runoff was more frequent

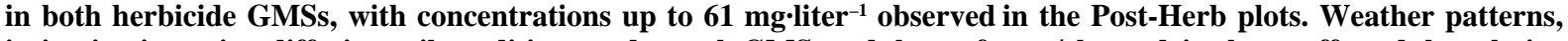
irrigation intensity, differing soil conditions under each GMS, and the turfgrass/clover drive lanes affected the relative frequency and concentrations of benomyl and nitrate leaching and runoff. Preferential bypass flow appeared to be a major subsurface leaching pathway, and erosion sediment an important factor in surface movement of these agrichemicals. Our studies suggest that nitrate-N and benomyl fungicide may be more prone to leaching or runoff from orchard soils under some herbicide GMSs in comparison with mowed sodgrass or biomass mulch systems.
\end{abstract}

Intensive use of agrichemicals in modern agriculture has increased the risks of surface and groundwater contamination by fertilizers and pesticides, prompting serious public concern (National Resource Council, 1989). Annual pesticide inputs in apple orchards of the northeast United States have been estimated at $85 \mathrm{~kg} / \mathrm{ha}$, among the highest of any food crop (U.S. Dept. Agriculture, 1992). Climatic and edaphic requirements of commercial tree-fruit culture have led to concentrations of orchards on upland, coarse-textured soils near large bodies of water in areas of the Northeast where surface runoff and subsurface leaching of pesticides are likely to contaminate water supplies. A few researchers have sampled or monitored pesticide leaching or runoff from orchard soils, detecting limited movement of

Received for publication 31 Mar. 1995. Accepted for publication 9 Oct. 1995 Cornell Univ. Dept. of Fruit and Vegetable Science paper no. 56. This research was funded in part by the U.S. Dept. Agriculture Northeast Pesticide Impact Assessment Program, under subcontract to Pennsylvania State Univ., and also by U.S. Dept. Agriculture-CSRS Hatch Act Project NY(C)-142409), and U.S. Dept. Agriculture-NRI special grant funds. Critical reviews of the manuscript by M.P. Pritts, H.M. van Es, A.M. Petrovic, and the technical assistance of Kirstin Armstrong, Michael Rutzke, and Bonnie Lucas are gratefully acknowledged. The cost of publishing this paper was defrayed in part by the payment of page charges. Under postal regulations, this paper therefore must be hereby marked advertisement solely to indicate this fact.

${ }^{1}$ Assistant professor.

${ }^{2}$ Research technician.

${ }^{3}$ Associate professor.

${ }^{4}$ Research support specialist. persistent or weakly adsorbed chemicals through the soil profile into groundwater(Close, 1993; Jenkins et al., 1983; Kotcon and Wimmer, 1993; Veneman et al., 1983; Weaver et al., 1990 a, 1990b). Water pollution prevention and abatement plans currently being developed in the Northeast and elsewhere will require the evaluation of different management practices to minimize off-site movement of agrichemicals. Integrated Pest Management programs and advances in pesticide and sprayer technology have reduced the quantities and frequency of orchard pesticide applications (Klonsky et al., 1990; Kovach and Tette, 1988). But another factor that deserves attention is the potential impact of orchard soil or groundcover management systems (GMSs) on subsurface leaching and surface runoff of agrichemicals.

Simulation modeling, soil column, and field studies have shown that soil textural and physical conditions, tillage methods, agrichemical characteristics, and application practices are major factors in the retention, leaching, and runoff of agrichemicals (Canter, 1987; Carsel et al., 1984; Leonard et al., 1987; Levanon et al., 1993; Logan et al., 1987; Smith et al., 1991; Wauchope, 1978; Wauchope et al., 1992). The various soil and groundcover management systems used in orchards affect plant nutrient availability, soil water content, temperature, infiltration, and hydraulic conductivity, organic matter content, soil surface crusting and erosion, and tree root development in substantially different ways (Glenn and Welker, 1989; Haynes, 1981; Hogue and Neilsen, 1987; Merwin and Stiles, 1994; Merwin et al., 1994). Differences 
in soil conditions associated with different GMSs in orchards therefore could influence the relative rates and amounts of agrichemical runoff and leaching (Bush et al., 1991; Jury and Fluhler, 1992; Knisel, 1980; Leonard et al., 1987; Official Technological Assessment, 1990; Steenhuis et al., 1990; Wauchope et al., 1992). Despite the high chemical inputs in commercial fruit production and the various GMSs commonly used in orchards, there have been few research publications on the relationship between orchard GMSs and off-site movement of agrichemicals. Most fruit growers use herbicides or tillage to control weeds within tree rows in humid regions, or over the entire orchard floor in regions where irrigation is necessary. These weed control systems provide effective and economical control of weed interference with the fruit crop, but in comparison with other GMSs, such as mulches or mowed turfgrass, their relative impacts on the environmental fate of agrichemicals have not been adequately determined.

Agrichemical movement in soils has been studied most extensively with constructed or extracted soil columns, or computer programs based upon mathematical models intended to simulate the leaching behavior of fertilizers and pesticides under different soil and climatic conditions (Carsel et al., 1984; Hutson and Wagenet, 1992; Jury and Fluhler, 1992; Leonard et al., 1987; Smith et al., 1991; Steenhuis et al., 1987). The validation of laboratory and simulation models with field-scale observations under realistic crop production conditions is difficult, and has limited their development and utilization by environmental research and regulatory agencies (Ghodrati and Jury, 1990; Jabro et al., 1993; Jury and Fluhler, 1992; Steenhuis et al., 1994a). At present, simulation models may therefore be more appropriate for comparing the relative probabilities of off-site pesticide movement with different chemicals or application practices than for predicting the actual magnitude of pesticide outflows from agricultural fields (Jury and Fluhler, 1992; Nutter et al., 1993). The objectives in our study were to monitor the flow patterns and concentrations of several agrichemicals in subsurface leachate and surface runoff water from a commercial apple orchard, and to test the hypothesis that different GMSs might influence the concentrations of a widely used fungicide and nitrate- $\mathrm{N}$ in vadose zone soil water from orchards.

\section{Materials and Methods}

Two separate experiments were conducted from 1991 to 1994. In Expt. 1, we investigated agrichemical movement through an apple orchard soil on a small scale in nonreplicated plots of two GMSs, using tracer analogs of weakly adsorbed pesticides and nitrate anion. In Expt. 2, we monitored pesticide movement on a whole-field scale, using replicated drainage and runoff sampling systems in large orchard plots under four different GMSs.

\section{Experiment 1}

These tests were conducted in a long-term orchard GMS study at Ithaca, N.Y. The soil is a silty-clay loam (mixed, mesic, Aeric Ochraqualf) with $4 \%$ to $6 \%$ slopes, $\mathrm{pH}$ of 6.2 to 7.0 , and soil organic matter content averaging $4.5 \%$ to $6.2 \%$. Apple trees were planted at 3 by 6-m spacing in April 1986, and different GMS treatments were established and continuously maintained in $2.5 \times 25-\mathrm{m}$ plots, separated by $3.5-\mathrm{m}$-wide grassed drive lanes. Soil physical conditions and tree responses to the various GMSs at the time of these experiments have been described elsewhere (Merwin and Stiles, 1994; Merwin et al., 1994). In 1991, we selected two $2.5 \times 5$-m subplots where 6 years of repeated glyphosate ( $\mathrm{N}$-phosphono-methyl-glycine) herbicide applications ( $2 \mathrm{~kg}$ active ingredient (a.i.) per ha in mid May and July each year), or periodic mowing of a red fescue (Festuca rubra L.) turfgrass had created distinct soil structural characteristics. Beneath the turfgrass plots a dense fibrous root system and crumbly soil structure without continuous surface cracks developed. In the glyphosate plots a $0.2-\mathrm{cm}$-thick layer of perennial moss had developed and an extensive network of large, deep cracks was visible on the surface during summer months.

In 1991, we installed an underground drainage system to monitor chemical tracer movement beneath trees in one Mowed-Sod and one Post-Herb plot. Trenches were dug parallel to the tree-row plots with a backhoe, about 2-m distance from two trees in each plot. Horizontal tunnels were then excavated laterally from adjacent trenches at 60 to $160 \mathrm{~cm}$ depth beneath two trees in each GMS plot, without disturbing the surface. Grids $30 \times 30 \mathrm{~cm}$ wide, containing 25 wick-pan and gravity-pan lysimeters attached to separate sample collection bottles, were placed in contact with the soil roof in each tunnel at $60 \mathrm{~cm}$ depth beneath trees in both plots (Steenhuis et al., 1992). Water infiltration and the relative rates and patterns of solute leaching beneath each GMS were monitored using two tracers: brilliant blue food dye (a weakly adsorbed $\left(\mathrm{K}_{\mathrm{oc}}=131\right)$, a large organic molecule with leaching characteristics analogous to some pesticides with low soil-sorption indices), and potassium bromide to provide a nitrate analog (Flury and Fluhler, 1995). A pulse of blue dye and bromide at $1000 \mathrm{mg} \cdot$ liter ${ }^{1}$ concentrations was applied in $3.5 \mathrm{~cm}$ of irrigation water on day one, followed by $2-\mathrm{cm}$ of sprinkler irrigation daily for 25 days (Ghodrati and Jury, 1990; Steenhuis et al., 1994b). The concentrations of blue dye or bromide in water captured by subsurface sample bottles were then determined by direct-read spectrometry or specific ion probe analyses, at fixed intervals following surface sprinkler applications of the tracers and subsequent irrigations. This preliminary experiment provided data with high spatial and temporal resolution for evaluating the relative importance of matrical and preferential leachate flows under long-term Mowed-Sod and Post-Herb treatments.

\section{Experiment 2}

Subsurface drainage and surface runoff sampling system. In 1991, we installed a replicated grid of perforated polyvinyl-chloride (PVC) drainage lines under a 0.8-ha site on the east shore of Cayuga Lake, near Ithaca, N.Y. The soil is a relatively uniform silty clay loam (mixed, mesic, Glosaquic Hapludalf) with $\mathrm{pH}$ of 6.8 to 7.2 and organic matter content of $4.7 \%$ to $5.3 \%$. The site was previously planted with apple trees for 15 years. When the old trees were removed in April 1991 the field was limed, deep plowed, cultivated, and seeded to a creeping red fescue turfgrass. Apple trees were planted at $3 \times 6-\mathrm{m}$ spacing in April 1992, and three replications of four GMS treatments were randomly assigned to twelve independently drained plots, each containing 20 trees, located in a moderately sloped ( $8 \%$ to $10 \%$ incline) area of the site. Plots were $9 \mathrm{~m}$ wide across-slope and 25-m long down-slope, situated in two long blocks each containing four continuous tree rows separated by 4-m-wide turfgrass drive lanes between the 2-m-wide GMS-treated areas beneath trees. Each of the 12 subsurface drainage systems captured leachate from three grassed drive lanes and the four treated tree rows comprising each GMS replicate. A surface runoff diversion ditch and subsurface drainage line were installed at the upper edge of the site to intercept incoming water. All plots were hydrologically isolated from each other by installing perimeter drainage interception lines at $0.8 \mathrm{~m}$ depth in 6-m-wide surrounding buffer zones. A single perforated PVC line was buried at $0.7 \mathrm{~m}$ depth down the center of every GMS plot, draining to the down-slope edge of the treatment area, and then coupled through solid PVC pipes to a below-ground access station where the subsurface leachate from individual plots could be sampled. Surface runoff was collected in grade-level sample bottles behind 2- 
m-wide semicircular steel weirs driven into the soil at the lower edge of GMS plots. A micro-sprinkler irrigation system was installed, delivering $0.3 \mathrm{~cm}$ water/ha over the surface of all tree-row treatment areas when necessary to obtain leachate or runoff water samples.

Four GMS treatments were established and maintained continuously in 2-m-wide strips within the tree rows. 1) Mowed-Sod: The red fescue turfgrass originally seeded in 1991, including some white clover (Trifolium repens L.) that self-established during the second and third summers, mowed monthly during each growing season; 2) Post-Herb: Postemergence applications of glyphosate herbicide at a rate of $2 \mathrm{~kg}$ a.i./treated ha in mid-May and July each year; 3) Resid-Herb: Preemergence applications of paraquat (1,1'-dimethyl-4,4'-bipyridinium ion), norflurazon (4chloro-5-methylamino)-2-(3-(trifluoromethyl) phenyl)-3(2H)pyridazinone), and diuron (N'-(3,4-dichlorophenyl)-N, Ndimethylurea) residual herbicides, tank-mixed at $0.5,3.0$, and 2.5 $\mathrm{kg}$ a.i./ha, respectively, each year in mid April; and 4) BarkMulch: A $15 \mathrm{~cm}$ layer of shredded hardwood bark mulch applied in May 1992, then spot-sprayed with glyphosate in mid July 1993 and 1994, as needed to control weeds in the mulch layer. We chose benomyl for monitoring because it is widely used in orchards, has a relatively long soil half life (180 to 360 days), low vapor pressure, and water solubility, and a high soil sorption index $\left(\mathrm{K}_{\mathrm{oc}}\right.$ $=1900$ ). It is ranked as having small leaching and large surfaceloss potentials in the USDA/ARS/CES national pesticide database (Wauchope et al., 1992).

Pesticide and fertilizerapplications, andwateranalyses. Benomyl fungicide was applied in the orchard at various intervals each year as needed for apple disease control, at the label-recommended rate of $0.1 \mathrm{~kg}$ a.i./ha (a concentration of $234 \mu \mathrm{g}$ a.i./liter in the spray solution), using a tractor mounted airblast sprayer directed at the tree canopies. Because of the relatively small canopy volume of the young trees in this orchard, some spray deposition occurred over the entire site including the plot ground surface and grass drivelanes. Leachate samples were taken from 8-liter buckets suspended under the outfall pipe from each GMS plot, and were obtained before the first benomyl applications each spring, and then as often as possible when drainage flows occurred following benomyl applications and rainfall or irrigation. All samples were stored frozen at $-45 \mathrm{C}$ until they could be analyzed for benomyl (as carbendazim) concentrations by an enzyme linked immunosorbent assay (ELISA) with a minimum detection threshold of $0.1 \mu \mathrm{g} \cdot$ liter $^{-1}$ and negligible cross-reactivity (Ohmicron Co., Newtown, Pa.) Ammonium-nitrate fertilizer was applied on the soil surface beneath each tree at rates of 30,45 , and $65 \mathrm{~kg} \mathrm{~N} / \mathrm{ha}$ in mid April 1992, 1993 and 1994, respectively. Foliar sprays of calciumnitrate fertilizer $(0.15 \mathrm{~kg} \mathrm{~N} / \mathrm{ha})$ were applied to trees on day $133 \mathrm{in}$ 1993, and days 123 and 158 in 1994. Nitrate concentrations were determined in water samples by the procedures of Vendrell and Zupancic (1990), and in soil samples by ammonium-acetate extraction and cadmium reduction; soil organic matter content was determined by loss on ignition at 500C (Greweling and Peech, 1965).

Statistical analyses. There were some occasions when leachate or runoff samples were obtained in most, but not all, of the GMS replicates or treatments in Expt. 2. On such occasions the zero-flow samples were treated as missing data points in our statistical analyses. This treatment retained the normal distribution of data, but resulted in unbalanced replicate numbers. As a consequence, our mean separations among GMSs were conservative, but unbiased. During sustained leachate outflows multiple samples were obtained from each plot, but the sampling buckets also overflowed between samples, so each sample represented a cumulative average of leachate concentrations during the time interval since the previous sample. Outflow breakthroughs sometimes occurred late one day in some treatment replicates, and early the next day in others. Every sample obtained was analyzed separately for benomyl and nitrate-N content, but in the final data tabulation for statistical analyses we considered sequential samples spanning 2 days but representing a discrete outflow event from each of the 12 plots as a single daily replicate. We used the maximum (not the mean of two) concentration values observed in sequential samples from the same plot on a single day for statistical analyses. The data presented in this report, therefore, represent means of the maximum benomyl or nitrate concentrations detected in each GMS replicate during each sampling interval.

There were 25 replicate sampling lysimeters in each plot, but no replications of GMS treatments in Expt. 1. For Expt. 2, 3 years of leachate data for benomyl and 2 years for nitrate-N concentrations were initially analyzed as a two-way factorial ANOVA model with block position (upper or lower slope) entered as a covariate, and years and GMS treatments as main factors. Because the GMS $\times$ year interactions were significant $(P<0.01)$ in the pooled 3-year ANOVA, we subsequently analyzed separately the leachate data within each year, and treatment means were separated when appropriate by Fisher's protected least significant differences. No surface runoff was detected in several GMSs on most sampling dates. We could not use ANOVA for the pooled yearly runoff data, but treatment mean separations were possible on six sampling dates, and the relative frequencies of runoff events were compared among the GMSs.

\section{Results and Discussion}

\section{Experiment 1}

During the first day of tracer infiltrations, the blue dye and

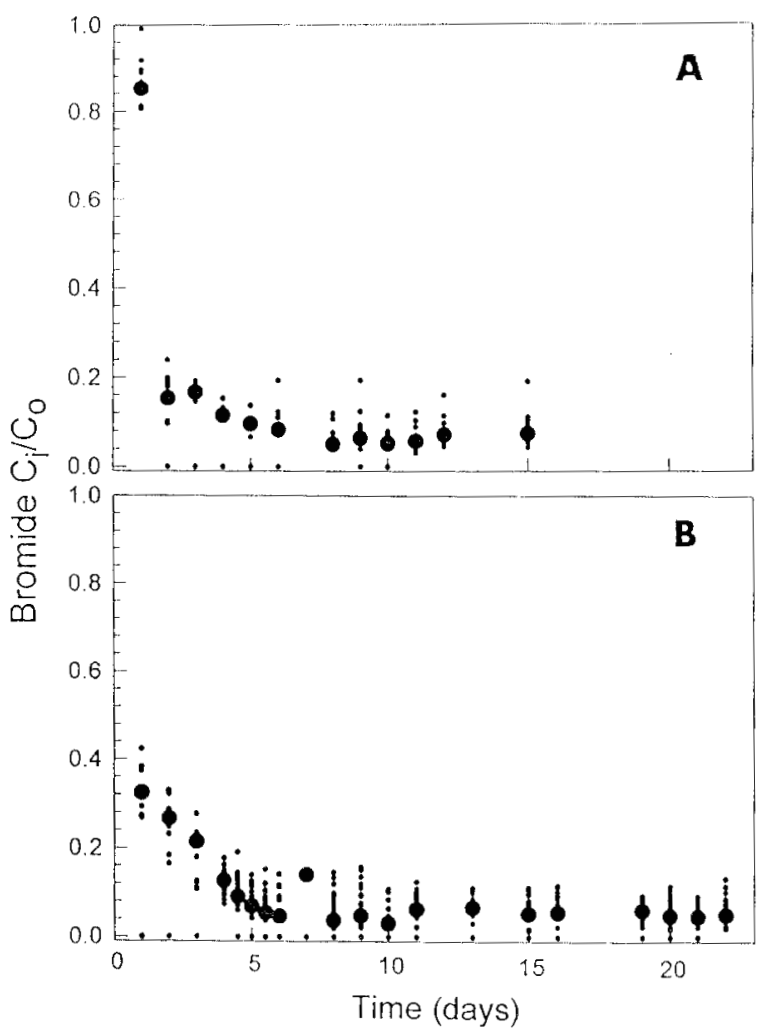

Fig. 1. Kat1o ot surtace-sprınkler applied $\left(\mathrm{C}_{\mathrm{o}}\right)$ and captured $\left(\mathrm{C}_{\mathrm{i}}\right)$ bromide (nitrate analog) concentrations observed in gravity-type leachate samplers at $60 \mathrm{~cm}$ depth, during subsequent 2-cm daily irrigations of an orchard soil beneath PostHerb (A) and Mowed-Sod (B) groundcover management systems, in July 1991. Larger dots are means of 25 samples on each day. 

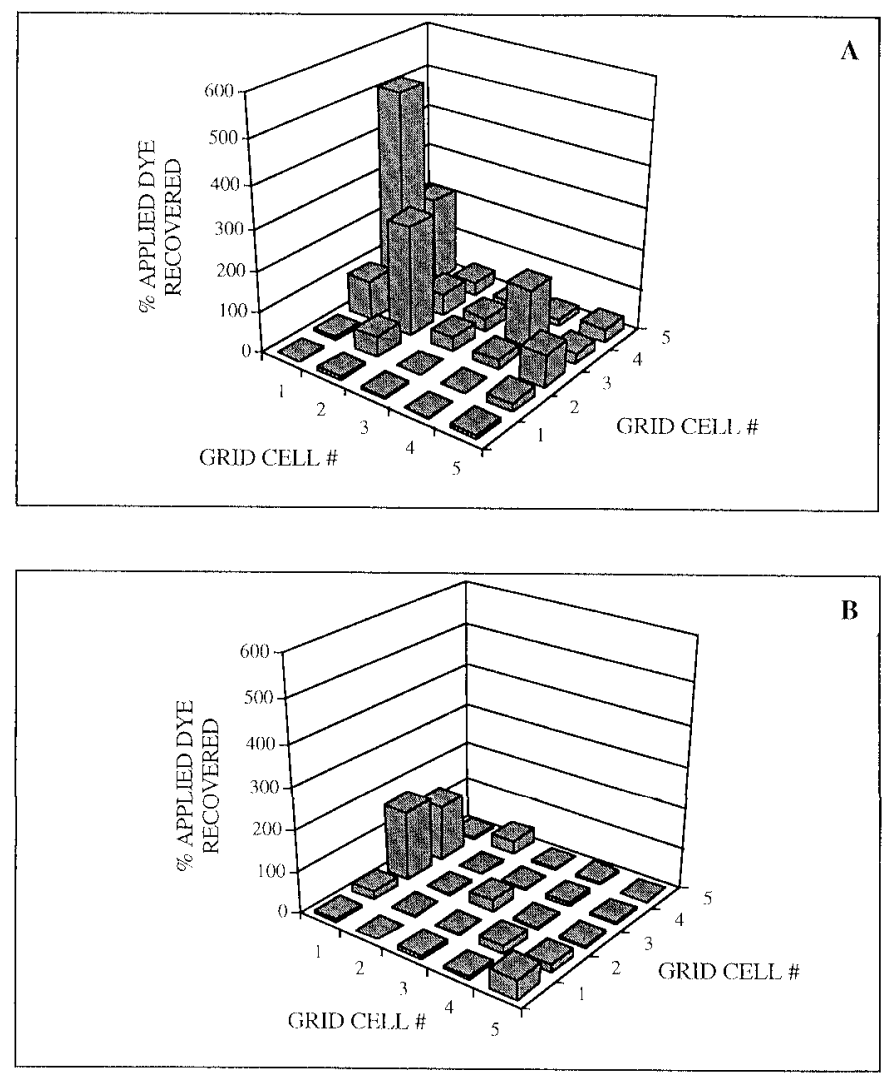

Fig. 2. Cumulative spatial distribution of blue-dye leachate captured (dye recaptured in each subsurface sampler/dye applied to equivalent surface area) $\times 100$ in a $5 \times 5$ grid, $30 \times 30 \mathrm{~cm}$ wide, of wick sampler bottles at $60-\mathrm{cm}$ depth beneath apple trees in Post-Herb (A) and Mowed-Sod (B) groundcover management systems, in 20 daily irrigations after dye infiltration, July 1991.

bromide were detected in subsurface lysimeter samplers at substantially higher concentrations under the Post-Herb compared with the Mowed-Sod treatment (Figs. 1 A and B and $2 \mathrm{~A}$ and B). Both tracers initially leached through at $85 \%$ to $90 \%$ of the surface-applied concentration under the PostHerb plot (Fig. 1A). In contrast, tracer concentrations detected initially under the Mowed-Sod plot were much lower (Fig. 1B), indicating more intimate contact and retention of dye within the soil matrix beneath the sodgrass. Concentrations of bromide and dye peaked the first day after application in both GMSs, decreased rapidly during the next few days, and then diminished asymptotically during subsequent irrigations.

The spatial pattern of dye percolation detected by the $5 x$ 5 grid of wick-pan samplers was markedly nonuniform under both GMSs, and chisquared analyses confirmed that deviation from mean values for the 25 samplers was significant $(P<0.001)$ in both

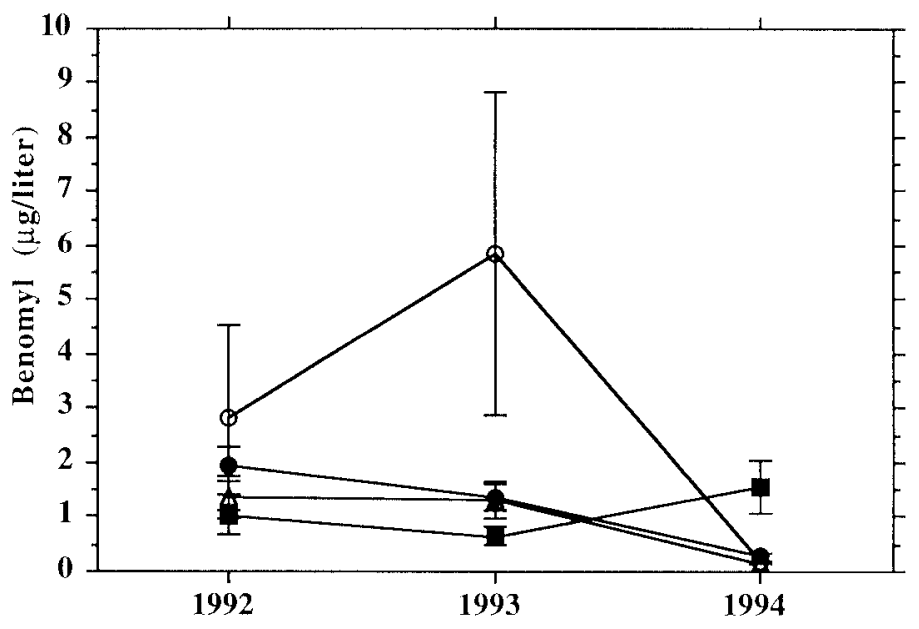

Fig. 3. GMS $\times$ year interaction for benomyl concentrations in subsurface leachate under four GMSs $(\mathrm{O}=$ Resid-Herb, $\square=$ Post-Herb, $\Delta=$ Mowed Sod, $\boldsymbol{O}=$ BarkMulch), with standard errors for the means of at least 80 observations in each GMS, during 3 consecutive years of sampling.

plots (Fig. 2 A and B). Moreover, the cumulative proportion of blue dye funneled through preferential pathways and concentrated into a relatively few of the samplers (i.e., the percentage ratio of dye amounts recaptured in each subsurface lysimeter vs. amounts applied to the equivalent surface area) during 20 days of subsequent irrigations was about 3 -fold greater under the Post-Herb than the Mowed-Sod plots, suggesting more retention of the weakly adsorbed pesticide analog in the Mowed-Sod topsoil.

\section{Experiment 2}

Subsurface benomyl leaching. When treatment effects on leachate benomyl concentrations were analyzed within years, there were significant differences among the GMSs in $1992(P<$ $0.10)$ and $1994(P<0.01)$, and also among the different sampling days in 2 of the 3 years $(P<0.001)$ (Table 1$)$. Observed subsurface

Table 1. Yearly analysis of variance results for benomyl and nitrate-N leachate concentrations under four different GMSs in a New York orchard, sampled 1992 to 1994.

\begin{tabular}{lcccc}
\hline \hline Year-Chemical & Source of variation & df & Mean square & $P$ value \\
\hline 1992-Benomyl & GMS & 3 & 4.713 & 0.10 \\
& Day of year & 7 & 38.054 & 0.0001 \\
& GMS $\times$ day & 18 & 3.644 & 0.07 \\
& Residual & 51 & 2.159 & \\
1993-Benomyl & GMS & 3 & 27.346 & 0.33 \\
& Day of year & 16 & 84.035 & 0.0001 \\
& GMS $\times$ day & 48 & 35.487 & 0.04 \\
& Residual & 108 & 23.663 & \\
$1994-$ Benomyl & GMS & 3 & 18.958 & 0.003 \\
& Day of year & 15 & 2.123 & 0.896 \\
& GMS $\times$ day & 45 & 1.790 & 0.997 \\
& Residual & 106 & 3.767 & \\
$1993-N i t r a t e-N$ & GMS & 3 & 251.437 & 0.0001 \\
& Day of year & 16 & 46.284 & 0.0001 \\
& GMS $\times$ day & 48 & 9.776 & 0.78 \\
& Residual & 108 & 6.991 & \\
$1994-N i t r a t e-N$ & GMS & 3 & 1807.789 & 0.0008 \\
& Day of year & 15 & 1726.808 & 0.0001 \\
& GMS $\times$ day & 45 & 449.054 & 0.05 \\
\hline
\end{tabular}


Table 2. Concentrations of benomyl fungicide in subsurface leachate water sampled beneath four GMSs during 1992, 1993 , and 1994.

\begin{tabular}{|c|c|c|c|c|c|c|c|c|c|c|c|c|c|c|c|c|c|}
\hline \multicolumn{18}{|c|}{ Day of year, 1992} \\
\hline \multicolumn{2}{|l|}{$\mathrm{GMS}^{\mathrm{z}}$} & \multicolumn{2}{|l|}{182} & $\nabla 191$ & \multicolumn{2}{|r|}{196} & \multicolumn{2}{|c|}{$\nabla 210$} & \multicolumn{2}{|c|}{212} & 218 & \multicolumn{2}{|c|}{$231 \nabla$} & \multicolumn{2}{|l|}{240} & & \\
\hline \multicolumn{2}{|l|}{ Mowed-Sod } & \multicolumn{2}{|c|}{$0.1^{y}$} & 0.6 & \multicolumn{2}{|r|}{0.1} & \multicolumn{2}{|c|}{4.1} & \multicolumn{2}{|c|}{2.3} & 0.2 & \multicolumn{2}{|c|}{2.6} & \multicolumn{2}{|l|}{0.8} & & \\
\hline \multicolumn{2}{|l|}{ Bark-Mulch } & \multicolumn{2}{|l|}{0.4} & 1.4 & \multicolumn{2}{|r|}{1.2} & \multicolumn{2}{|c|}{4.6} & \multicolumn{2}{|c|}{3.2} & 0.5 & \multicolumn{2}{|c|}{2.6} & \multicolumn{2}{|l|}{1.9} & & \\
\hline \multicolumn{2}{|l|}{ Post-Herb } & \multicolumn{2}{|l|}{0.0} & 0.3 & \multicolumn{2}{|r|}{0.4} & \multicolumn{2}{|c|}{5.2} & 1.1 & & 0.1 & & .5 & 0.7 & & & \\
\hline Resid-Herb & & --- & & --- & & 1.0 & & 0.5 & 0.1 & & 0.1 & --- & & 1.1 & & & \\
\hline Cum. $\mathrm{H}_{2} \mathrm{O}^{\mathrm{x}}$ & & 23 & & 30 & & 34 & & & 46 & & 46 & 47 & & 53 & & & \\
\hline Pooled mean & for 19 & & & & & & & & & & & & & & & & \\
\hline Mowed-Soc & & 1.4 & & & & & & & & & & & & & & & \\
\hline Bark-Mulch & & 2.0 & & & & & & & & & & & & & & & \\
\hline Post-Herb & & 1.0 & & & & & & & & & & & & & & & \\
\hline Resid-Herb & & 2.8 & & & & & & & & & & & & & & & \\
\hline SE means ${ }^{w}=$ & $=0.4, P$ & 0.10 & & & & & & & & & & & & & & & \\
\hline SE interactic & $\mathrm{ns}=0$ & $P<0.1$ & & & & & & & & & & & & & & & \\
\hline & & & & & & & Day & of year, & 1993 & & & & & & & & \\
\hline GMS & $\nabla 146$ & $\nabla 159$ & 160 & 167 & $172 \nabla$ & 180 & 186 & $\nabla 190$ & 196 & $201 \nabla$ & 215 & $\nabla 224$ & 230 & $\nabla 237$ & 244 & 246 & 250 \\
\hline Mowed-Sod & 1.3 & 0.8 & 6.8 & 4.3 & 0.8 & 0.2 & 0.1 & 3.6 & 0.2 & 0.2 & 0.3 & 1.9 & 0.2 & 0.1 & 0.6 & 0.4 & 0.4 \\
\hline Bark-Mulch & 1.6 & 1.5 & 1.3 & 3.0 & 0.9 & 0.9 & 0.6 & 5.0 & 0.4 & 0.3 & 0.4 & 4.2 & 1.2 & 0.2 & 1.1 & 0.3 & 0.2 \\
\hline Post-Herb & 0.3 & 0.5 & 1.4 & 2.5 & 0.2 & 0.2 & 0.2 & 3.8 & 0.2 & 0.2 & 0.2 & 0.6 & 0.3 & 0.1 & 0.1 & 0.2 & 0.2 \\
\hline Resid-Herb & 0.7 & 0.9 & 1.4 & 2.1 & 0.7 & 0.4 & 0.2 & 22.8 & 0.5 & 0.4 & 0.6 & 29.0 & 1.1 & 0.2 & 0.6 & 0.6 & 0.8 \\
\hline Cum. $\mathrm{H}_{2} \mathrm{O}$ & 4 & 11 & 12 & 13 & 15 & 22 & 24 & 28 & 29 & 30 & 38 & 47 & 49 & 53 & 56 & 58 & 60 \\
\hline
\end{tabular}

Pooled means for 1993

Mowed-Sod 1.3

Bark-Mulch 1.4

Post-Herb 0.6

Resid-Herb 5.9

SE means $=1.4, P>0.10$

SE interactions $=2.8, P<0.05$

Day of year, 1994

\begin{tabular}{lcccccccccccccccc} 
GMS & 106 & $121 \boldsymbol{\nabla}$ & 128 & $\boldsymbol{\nabla} 152$ & 165 & $\boldsymbol{\nabla} 176$ & 178 & 181 & $\boldsymbol{\nabla} 188$ & 201 & 208 & 220 & $\boldsymbol{\nabla} 227$ & 230 & 233 & 241 \\
\hline Mowed-Sod & 0.0 & 0.0 & 0.0 & 0.1 & 0.0 & 0.5 & 0.2 & 0.2 & 0.3 & 0.1 & 0.1 & 0.0 & 0.0 & 0.6 & 0.1 & 0.4 \\
Bark-Mulch & 0.0 & 0.0 & 0.0 & 0.1 & 0.1 & 0.6 & 0.1 & 0.7 & 1.3 & 0.1 & 0.4 & 0.2 & 0.1 & 0.6 & 0.1 & 0.4 \\
Post-Herb & 0.1 & 0.1 & 3.9 & 1.3 & 0.3 & 2.3 & 3.7 & 2.3 & 5.7 & 0.2 & 2.0 & 1.0 & 0.5 & 0.3 & 0.1 & 1.4 \\
Resid-Herb & 0.0 & 0.0 & 0.0 & 0.1 & 0.1 & 0.4 & 0.3 & 0.2 & 0.3 & 0.1 & 0.2 & 0.1 & 0.1 & 0.7 & 0.1 & 0.2 \\
Cum. $\mathrm{H}_{2} \mathrm{O}$ & 3 & 8 & 10 & 14 & 17 & 19 & 20 & 21 & 23 & 28 & 31 & 35 & 41 & 51 & 54 & 56
\end{tabular}

Pooled means for 1994

Mowed-Sod 0.2

Bark-Mulch 0.3

Post-Herb 1.6

Resid-Herb $\quad 0.2$

SE means $=0.6, P<0.01$

SE interactions $=1.1, P>0.10$

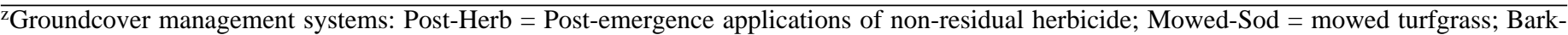
Mulch = shredded bark mulch; Resid-Herb = Residual preemergence herbicide applications.

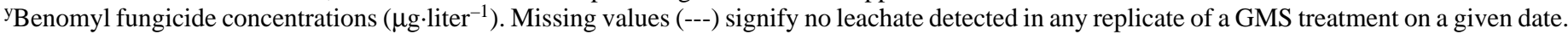

${ }^{\mathrm{x}}$ Cumulative rainfall plus irrigation $(\mathrm{cm})$ beginning on 1 Apr. and ending on final sampling day each year.

${ }^{\text {w}}$ Standard error for means of three replications of each GMS treatment, and standard error for GMS $\times$ day interactions, pooled over growing season.

IIndicate times of benomyl applications each year: 1992-190, 209, 232; 1993-140, 154, 174, 190, 208, 221, 237; 1994-123, 147, 171, $187,227$.

flows and benomyl concentrations varied substantially among different years and GMSs in our field-scale tests, especially in the Resid-Herb treatment (Fig. 3). Although we sometimes estimated short-term flow rates by timing grab samples of known volume from the outfall pipes, our drainage sampling system did not enable continuous measurements of flow rates. Reliable inferences about the actual magnitude (flow rates $\times$ chemical concentrations) of benomyl leaching from the test site were not possible, and cumulative transport of benomyl or nitrates in water from this orchard could not be determined with our test facilities. More prolonged drainage outflows were usually observed under the Bark-Mulch plots, and the soil water potential (measured with tensiometers in each plot) remained higher between irrigations under the BarkMulch than the other three GMS treatments on most occasions. Briefer and less frequent pulses, and lower rates of subsurface drainage outflow from Resid-Herb plots were observed throughout this study.

Benomyl was applied during 1992 on days 190, 209, and 232, and was detected in subsurface leachate following each application and subsequent rainfall or irrigation (Table 2). Nine samples were col- 
Table 3. Concentrations of benomyl fungicide in surface water runoff sampled from four GMSs in an orchard during 1993 and 1994.

\begin{tabular}{|c|c|c|c|c|c|c|c|c|c|c|c|c|c|c|c|c|c|c|}
\hline \multirow[b]{2}{*}{$\mathrm{GMS}^{\mathrm{z}}$} & \multicolumn{18}{|c|}{ Day of year, 1993} \\
\hline & $\nabla 160$ & 167 & $172 \nabla$ & 180 & 186 & $\nabla 190$ & 196 & \multicolumn{2}{|c|}{201} & $\boldsymbol{\nabla} 209$ & 215 & $\nabla 223$ & 229 & $\nabla 237$ & 243 & 246 & 250 & 273 \\
\hline Mowed-Sod & $--^{y}$ & 5.3 & 2.9 & --- & --- & 81.7 & --- & \multicolumn{2}{|l|}{---} & --- & --- & --- & --- & --- & --- & --- & --- & --- \\
\hline Bark-Mulch & --- & --- & 2.5 & --- & --- & 44.1 & --- & \multicolumn{2}{|l|}{---} & --- & --- & --- & --- & --- & --- & --- & --- & --- \\
\hline Post-Herb & --- & 7.0 & 4.1 & --- & --- & 50.3 & --- & \multicolumn{2}{|l|}{---} & --- & --- & --- & --- & --- & --- & --- & 2.7 & --- \\
\hline Resid-Herb ${ }^{\mathrm{x}}$ & 23.2 & 18.8 & 7.7 & 19.4 & 5.1 & 387.3 & 1.6 & \multicolumn{2}{|c|}{4.8} & 14.6 & 6.2 & 37.6 & 1.7 & 0.9 & 2.5 & 3.1 & \multirow{2}{*}{$\begin{array}{l}1.2 \\
60\end{array}$} & 1.0 \\
\hline \multirow{2}{*}{ Cum. $\mathrm{H}_{2} \mathrm{O}$} & 12 & 13 & 15 & 22 & 24 & 28 & 29 & \multicolumn{2}{|l|}{30} & 31 & 38 & 47 & 49 & \multicolumn{2}{|l|}{53} & 58 & & 65 \\
\hline & \multicolumn{18}{|c|}{ Day of year, 1994} \\
\hline GMS & $\nabla 152$ & & 165 & $\nabla 175$ & 176 & 178 & 18 & & 181 & & $\nabla 188$ & 208 & 211 & 22 & 20 & $\nabla 227$ & 230 & 241 \\
\hline Mowed-Sod & --- & & 0.2 & --- & --- & --- & --- & & --- & & --- & --- & --- & --- & & 0.2 & 5.2 & 1.8 \\
\hline Bark-Mulch & --- & & 0.3 & --- & 2.9 & --- & --- & & --- & & --- & 1.2 & --- & --- & & 0.2 & 3.3 & 1.2 \\
\hline Post-Herb & 0.2 & & 0.3 & 60.7 & 23.7 & 3.9 & & & 2.5 & & 2.9 & 4.3 & 0.4 & & .9 & 0.4 & 7.2 & 2.4 \\
\hline Resid-Herb & 0.3 & & 0.2 & 19.9 & 4.6 & 1.6 & & & 2.8 & & 1.4 & 1.8 & 1.0 & & .5 & 0.5 & 5.4 & 2.0 \\
\hline Cum. $\mathrm{H}_{2} \mathrm{O}$ & 14 & & 17 & 19 & 19 & 20 & 21 & & 21 & & 23 & 31 & 32 & 35 & & 41 & 51 & 56 \\
\hline
\end{tabular}

${ }^{\mathrm{z}}$ Groundcover management systems: Post-Herb = Post-emergence applications of non-residual herbicide; Mowed-Sod = mowed turfgrass; BarkMulch $=$ shredded bark mulch; Resid-Herb $=$ Residual preemergence herbicide applications.

${ }^{\mathrm{y}}$ Benomyl fungicide concentrations $\left(\mu \mathrm{g} \cdot \mathrm{liter}{ }^{-1}\right)$. Missing values (---) signify no runoff detected in any replicate of a GMS treatment on a given date. ${ }^{\mathrm{x}}$ Cumulative rainfall plus irrigation $(\mathrm{cm})$ beginning on 1 Apr. and ending on final sampling day each year.

$\boldsymbol{\nabla}$ Symbols indicate times of benomyl applications each year: 1992-190, 209, 232; 1993-140, 154, 174, 190, 208, 221, 237;1994---123, 147, 171, $187,227$.

lected from Resid-Herb plots, and 24 from each of the other GMSs on eight sampling dates during the growing season. Preliminary samples were obtained on day 182 (before our first benomyl application) to evaluate the residual soil carryover of this fungicide from 15 years of previous pesticide applications at the site. No outflow was observed in any Resid-Herb plot on that date, and residual benomyl concentrations were below the ELISA detection threshold (0.1 $\mu \mathrm{g} \cdot$ liter $^{-1)}$ in five plots, and $<0.5 \mu \mathrm{g} \cdot \mathrm{liter}^{-1}$ in all samples. Peak concentrations of benomyl $\left(10 \mu \mathrm{g} \cdot\right.$ liter $\left.^{-1}\right)$ occurred on day 210 in the Resid-Herb plots. However, concentrations of benomyl were barely detectable in the Resid-Herb outflows 2 days later, whereas the fungicide was released more gradually under Bark-Mulch and MowedSod treatments from days 210 to 218 . Detectable outflow had ceased under the Resid-Herb plots by day 231, while outflows and elevated benomyl concentrations continued in the other GMSs on that date. Pooled seasonal mean benomyl concentrations for 1992 were somewhat higher in Resid-Herb than in Post-Herb or Mowed-Sod plots, and the GMS $\times$ day interaction was significant $(P<0.10)$.

Seven benomyl sprays were applied in 1993, and we obtained 24 leachate samples from the Resid-Herb plots and 51 from each of the other three GMSs, on 17 sampling dates during the growing season (Table 2). The weather was relatively dry in early summer, and during repeated benomyl applications at the site leachate concentrations remained relatively low, peaking at 7 and $4 \mu \mathrm{g} \cdot \mathrm{liter}^{-1}$ in the MowedSod plots on days 160 and 167, respectively. The largest average benomyl concentrations (23 and $29 \mu \mathrm{g} \cdot \mathrm{liter}^{-1}$ on days 190 and 224, respectively) were observed in Resid-Herb plots when heavy rainfalls occurred shortly after fungicide applications. Concentrations again declined more rapidly after the peak breakthroughs in the Resid-Herb plots compared with the other GMSs (e.g., days 190 to 196, and 224 to 230). The relative benomyl concentrations among GMSs varied greatly from one sampling date to the next, and despite the higher average concentrations in the Resid-Herb leachate, the pooled treatment means for 1993 were not significantly different (Table 1).

Five benomyl sprays were applied in the orchard during 1994, and we obtained 32 leachate samples from Resid-Herb plots, 44 from Mowed-Sod plots, 47 from Bark-Mulch plots, and 48 from Post-Herb plots, on 15 sampling dates (Table 2). The maximum benomyl concentrations were lower than previous years, peaking at $6 \mu \mathrm{g} \cdot$ liter $^{-1}$ on day 188 in the Post-Herb treatment. There were few significant differences in leachate concentration among the GMS treatments on individual sampling dates, but the pooled seasonal mean concentrations were higher $(P<0.05)$ in the PostHerb plots than the other three GMSs during 1994. As in previous years, there were relatively more sampling dates when subsurface drainage outflow was not detected in some of the Resid-Herb replicates. On several occasions (e.g., days 152 and 227) heavy rainfalls occurred during the night, and it was likely that breakthrough benomyl concentrations in sampling buckets were diluted substantially by sustained outflows before we could collect leachate samples the next morning.

Surface benomyl runoff. Surface runoff capture in the sampling weirs occurred infrequently during three growing seasons at this orchard, usually during intense summer rainstorms but not during irrigation under non-saturated soil conditions. Consistent and substantial differences were observed in the frequency of runoff events among the various GMSs (Table 3). Measurable runoff occurred in the Bark-Mulch, Mowed-Sod, and Post-Herb plots on relatively few occasions in 1993 (days 167, 172, and 190). Runoff was more frequent in Resid-Herb plots, and relatively high concentrations of benomyl were detected in runoff from those plots, with one pulse of $387 \mu \mathrm{g} \cdot$ liter $^{-1}$ on day 190 . Comparison of leachate and runoff data on days 172 and 190 (Tables 2 and 3) indicated higher benomyl concentrations in surface runoff compared with subsurface drainage in all GMSs, confirming the USDA/ARS/CES pesticide properties database predictions for this fungicide (Wauchope et al., 1992). Peak benomyl concentrations were observed in both leachate and runoff outflows from Resid-Herb plots on day 190, suggesting that its leaching potential was also high.

During 1994, there were again fewer occasions when runoff occurred in the Mowed-Sod and Bark-Mulch than in other treatments. The largest runoff benomyl pulses were observed in the two herbicide GMSs from days 175 to 178 , but these concentrations also declined rapidly in surface runoff-as observed in subsurface flows in both our experiments. Visibly more sediments and suspended soil colloids were observed in runoff water samples from Resid-Herb plots during all three summers. Considering the high $\mathrm{K}_{\mathrm{oc}}$ sorption index and low water solubility $\left(2 \mathrm{mg} \cdot \mathrm{liter}^{-1}\right)$ of benomyl, and noting that the $387 \mu \mathrm{g} \cdot$ liter $^{-1}$ benomyl concentration 
Table 4. Nitrate-N concentrations in subsurface leachate water sampled beneath four GMSs in an orchard during 1993 and 1994.

\begin{tabular}{|c|c|c|c|c|c|c|c|c|c|c|c|c|c|c|c|c|c|}
\hline \multirow[b]{2}{*}{$\mathrm{GMS}^{\mathrm{z}}$} & \multicolumn{17}{|c|}{ Day of year, 1993} \\
\hline & $\nabla 146$ & 159 & 160 & 167 & 172 & 180 & 186 & 190 & 196 & 201 & 215 & 224 & 230 & 237 & 244 & 246 & 250 \\
\hline Mowed-Sod & $1.5^{\mathrm{y}}$ & 1.1 & 4.5 & 6.0 & 8.2 & 0.7 & 0.4 & 0.5 & 0.4 & 0.6 & 0.3 & 0.3 & 0.8 & 0.2 & 0.4 & 1.8 & 3.6 \\
\hline Bark-Mulch & 5.3 & 2.2 & 3.8 & 2.1 & 2.1 & 1.0 & 1.3 & 1.4 & 0.7 & 1.0 & 0.8 & 0.7 & 1.3 & 0.4 & 1.1 & 0.9 & 0.9 \\
\hline Post-Herb & 10.3 & 6.6 & 8.7 & 6.9 & 10.8 & 3.7 & 4.3 & 4.7 & 2.9 & 3.1 & 2.0 & 2.9 & 2.9 & 1.3 & 6.1 & 6.0 & 5.7 \\
\hline Resid-Herb & 6.5 & 5.7 & 16.2 & 19.6 & 7.4 & 8.5 & 4.1 & 3.2 & 6.0 & 6.2 & 6.2 & 6.3 & 6.2 & 1.3 & 7.6 & 5.3 & 10.6 \\
\hline Cum. $\mathrm{H}_{2} \mathrm{O}$ & 4 & 11 & 12 & 13 & 15 & 22 & 24 & 28 & 29 & 30 & 38 & 47 & 49 & 53 & 56 & 58 & 60 \\
\hline \multicolumn{18}{|c|}{ Pooled means for 1993} \\
\hline Mowed-Sod & 1.8 & & & & & & & & & & & & & & & & \\
\hline Bark-Mulch & 1.6 & & & & & & & & & & & & & & & & \\
\hline Post-Herb & 5.2 & & & & & & & & & & & & & & & & \\
\hline Resid-Herb & 7.6 & & & & & & & & & & & & & & & & \\
\hline \multicolumn{18}{|c|}{ SE means ${ }^{\mathrm{w}}=0.8, P<0.01$} \\
\hline \multicolumn{18}{|c|}{ SE interactions $=1.5, P<0.10$} \\
\hline & \multicolumn{17}{|c|}{ Day of year, 1994} \\
\hline GMS & $\nabla 106$ & $121 \nabla$ & 128 & 152 & $\nabla 1$ & & 176 & 178 & 181 & 188 & 201 & 208 & 220 & 227 & 230 & 233 & 241 \\
\hline Mowed-Sod & 56.6 & 43.0 & 9.6 & 65.7 & 52 & & 34.7 & 27.3 & 40.4 & 11.4 & 26.3 & 38.2 & 27.8 & 18.0 & 11.2 & 12.9 & 4.8 \\
\hline Bark-Mulch & 30.9 & 14.1 & 12.0 & 47.9 & 22 & & 16.5 & 2.7 & 7.7 & 2.7 & 26.4 & 25.4 & 13.7 & 11.5 & 11.8 & 10.0 & 2.3 \\
\hline Post-Herb & 23.2 & 18.7 & 17.9 & 7.6 & 27 & & 7.1 & 5.3 & 51.4 & 17.3 & 15.6 & 12.5 & 16.9 & 10.2 & 5.2 & 5.9 & 2.4 \\
\hline Resid-Herb & 41.8 & 62.4 & 58.8 & 65.5 & 29 & & 57.5 & 37.5 & 37.7 & 33.8 & 14.3 & 20.9 & 9.1 & 4.3 & 2.2 & 2.8 & 1.7 \\
\hline Cum. $\mathrm{H}_{2} \mathrm{O}$ & 3 & 8 & 10 & 14 & 17 & & 19 & 20 & 21 & 23 & 28 & 31 & 35 & 41 & 51 & 54 & 56 \\
\hline \multicolumn{18}{|c|}{ Pooled means for 1994} \\
\hline Mowed-Sod & 31.4 & & & & & & & & & & & & & & & & \\
\hline Bark-Mulch & 16.5 & & & & & & & & & & & & & & & & \\
\hline Post-Herb & 15.3 & & & & & & & & & & & & & & & & \\
\hline Resid-Herb & 29.4 & & & & & & & & & & & & & & & & \\
\hline \multicolumn{18}{|c|}{ SE means $=5.0, P<0.01$} \\
\hline SE interactiol & $=10.0$ & $P<0.05$ & & & & & & & & & & & & & & & \\
\hline
\end{tabular}

${ }^{\mathrm{z}}$ Groundcover management systems: Post-Herb = Post-emergence applications of non-residual herbicide; Mowed-Sod = mowed turfgrass; BarkMulch $=$ shredded bark mulch; Resid-Herb $=$ Residual preemergence herbicide applications .

${ }^{\mathrm{y}}$ Nitrate-N concentrations $\left(\mathrm{mg} \cdot \mathrm{liter}^{-1}\right)$. $\boldsymbol{\nabla}$ Symbols indicate ammonium-nitrate fertilizer applied beneath trees on day 105 in 1993 , day 103 in 1994 , and calcium-nitrate fertilizer applied in foliar tree sprays on days 133 in 1993, 123 and 158 in 1994.

${ }^{\mathrm{x}}$ Cumulative rainfall plus irrigation $(\mathrm{cm})$ beginning on 1 Apr. and ending on final sampling day each year.

${ }^{\mathrm{w}}$ Standard error for means of three replications of each GMS treatment, and standard error for GMS $\times$ day interactions, pooled over growing season.

in runoff on day 190 actually exceeded its $234 \mu \mathrm{g} \cdot$ liter $^{-1}$ concentration in the spray water applied at the orchard earlier that day, some concentration of the fungicide evidently occurred on eroded sediment accumulating in samples from the Resid-Herb plots. Measurements of surface sediment accumulation on the uphill side of runoff weirs after 3 years indicated that more erosion had occurred in Resid-Herb plots than in the other GMSs. The surface vegetation, biomass residues, and increased water infiltration in PostHerb, Mowed-Sod, and Bark-Mulch plots apparently reduced erosion and the associated sediment transport of the fungicide (Glenn and Welker, 1989; Haria et al., 1994; Merwin et al., 1994).

Subsurface nitrate leaching. Nitrate-N concentrations in leachate ranged from 0.1 to $20 \mathrm{mg} \cdot$ liter $^{-1}$ during the 1993 growing season (Table 4). On 16 of 17 sampling dates, nitrate-N concentrations were lower in the Mowed-Sod and Bark-Mulch plots compared with the Post-Herb and Resid-Herb treatments, and the pooled seasonal treatment means were also higher under both the herbicide treatments $(P<0.05)$. Average nitrate concentrations in Resid-Herb and Post-Herb leachate exceeded the $10 \mathrm{mg} \cdot$ liter $^{-1}$ U.S. EPA health advisory limit (HAL) for potable water on five occasions, but remained below that HAL concentration throughout the summer of 1993 in Mowed-Sod and Bark-Mulch GMSs. We began nitrate sampling earlier in 1994, and subsurface concentrations were greater in all treatments that year than 1993, but also more variable and difficult to interpret. Samples were obtained shortly after ground applications of ammonium nitrate on day 103 in 1994, and foliar applications of calcium nitrate on days 123 and 158. Nitrate concentrations were higher in all GMSs early that summer compared with later, and higher seasonal means were observed during 1994 in the Mowed-Sod and Resid-Herb treatments compared with Bark-Mulch and Post-Herb plots $(P<0.05)$.

Surface nitrate runoff. Nitrate concentrations were usually lower in surface runoff than in subsurface leachate during 1993 and 1994, and runoff events were more frequent and nitrate concentrations usually higher in outflows from the Resid-Herb plots (Table $5)$. These observations suggest an increased potential for surface loss of nitrates from orchards where preemergence herbicides are often used, and may be especially relevant in fruit-growing regions where fertilizer contamination of water resources is a major concern (Canter, 1987; Weinbaum et al., 1992).

It is important to consider the possible sources of nitrates in the leachate and runoff from our test site. The silt-loam soil at this orchard releases about $80 \mathrm{~kg} \mathrm{~N} /$ ha annually (Cline and Marshall, 1977). Nitrate-N concentrations in midsummer topsoil samples were greater after three years in the Resid-Herb plots compared with Mowed-Sod and Bark-Mulch (48 vs. $11 \mathrm{~kg} / \mathrm{ha}$, respectively), which may account for some of the higher nitrate concentrations in Resid-Herb leachate during 1993 and 1994 (Table 4). The increased nitrate leaching from all treatments in 1994 compared with 1993 suggests that increasing soil $\mathrm{N}$ applications from 45 to $65 \mathrm{~kg} \mathrm{~N} / \mathrm{ha}$, and doubling the number of foliar N applications in 1994 may have exceeded the orchard's ability to assimilate and retain nitrate- $\mathrm{N}$. The increased concentra- 
Table 5. Nitrate-N concentrations in surface water runoff sampled from four GMSs in an orchard during 1993 and 1994.

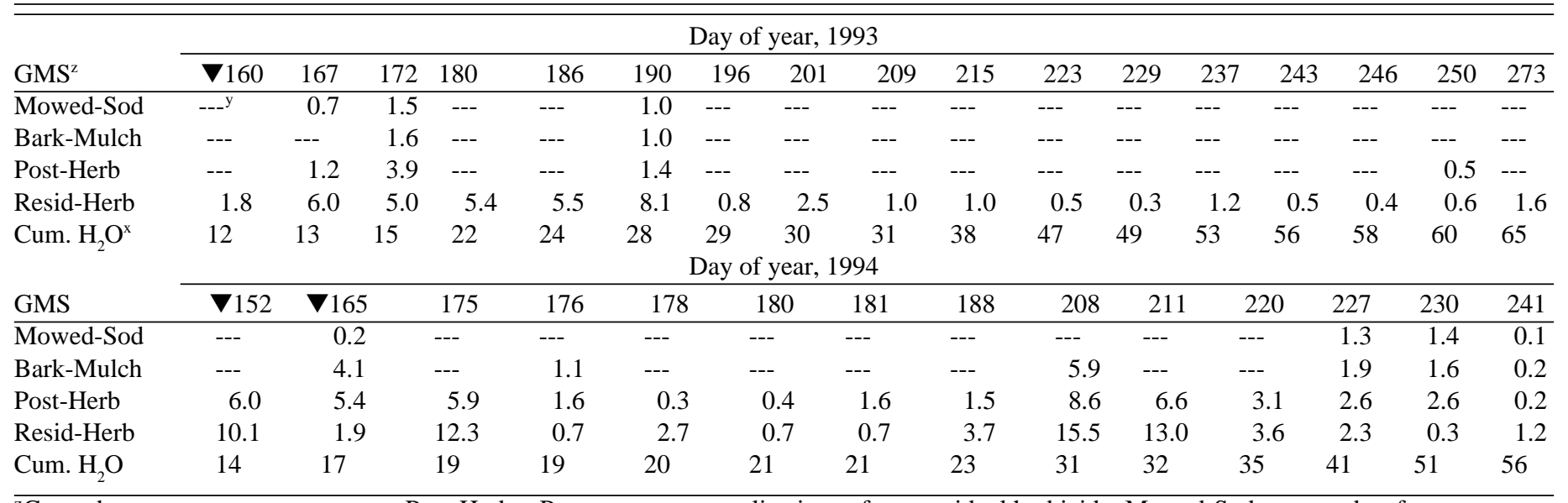

${ }^{\mathrm{z}}$ Groundcover management systems: Post-Herb = Post-emergence applications of non-residual herbicide; Mowed-Sod = mowed turfgrass; Bark-Mulch $=$ shredded bark mulch; Resid-Herb $=$ Residual preemergence herbicide applications.

yNitrate-N concentrations ( $\left.\mathrm{mg} \cdot \mathrm{liter}{ }^{-1}\right)$. Missing values (---) signify no runoff detected in any replicate of a GMS treatment on a given date. $\nabla$ Symbols indicate ammonium-nitrate fertilizer applied beneath trees on day 105 in 1993, day 103 in 1994, and calcium-nitrate fertilizer applied in foliar tree sprays on days 133 in 1993, 123 and 158 in 1994.

${ }^{x}$ Cumulative rainfall plus irrigation $(\mathrm{cm})$ beginning on $1 \mathrm{Apr}$. and ending on final sampling day each year.

tions in Mowed-Sod plots during 1994 may have been related to the development during successive years of a thick sod, and a marked increase in the amount of white clover in Mowed-Sod plots and all the drive lanes from 1992 to 1994, resulting in more $\mathrm{N}$ release and leaching from decomposing residues after monthly mowing within the sod GMS plots and drive lanes throughout the orchard (Petrovic, 1990). Because the drainage sampling systems also captured leachate from three drive lanes within each GMS replicate, the $\mathrm{N}$ leachate from mowed drive lanes should have been an equivalent background source for all the GMS treatments. We also noted that increased nitrate concentrations in Post-Herb leachate between days 178 and 181 in 1994 coincided with the decomposition of killed weed residues after the second glyphosate application on day 171 that summer. Two other nitrate sources were also considered-rainfall sampled at the site during July 1994 had a nitrate content of $0.4 \mathrm{mg} \cdot \mathrm{liter}^{-1}$, and the irrigation water drawn from Cayuga Lake had nitrate concentrations $<1 \mathrm{mg} \cdot$ liter $^{-1}$ — but neither would have been a confounding $\mathrm{N}$ source.

Conclusions. Benomyl fungicide is used extensively in fruit production, and multiple applications are common during the growing season for fruit disease control in orchards. No HAL has been established for benomyl by the U.S. EPA, but the allowable daily intake (ADI) in food is $0.02 \mathrm{mg} \cdot \mathrm{kg}^{-1}$ body weight for humans. To exceed this ADI, a $70 \mathrm{~kg}$ adult would need to ingest daily about 400 liters of subsurface leachate or 40 liters of surface runoff water at the maximum benomyl concentrations observed during 3 years of water monitoring at our test site. Hence, our data do not demonstrate that benomyl outflows from this orchard in surface or vadose-zone soil water posed a serious short-term human health hazard. However, we did observe substantial differences in retention and release of benomyl and nitrate- $\mathrm{N}$ from plots under different GMSs. As in other long-term studies of agrichemical runoff and leaching at field scale, the variability among treatments, sampling dates, and years in our data was substantial (Flury et al., 1994; Jabro et al., 1993). Our first experiment indicated that preferential flow was a major pathway for agrichemical movement in a 6-year-old orchard, and that these matric bypass breakthrough flows occurred more rapidly, and accounted for a greater proportion of chemical tracers leaching under Post-Herb compared with Mowed-Sod plots. In our second experiment, relatively higher benomyl concentrations were observed in leachate from preemergence Resid-Herb plots in 1992 and 1993, and from Post-Herb plots in 1994 (Table 2). Surface benomyl and nitrate runoff were detected less frequently in the Mowed-Sod and Bark-Mulch plots, despite many intense rainstorms, frequent irrigation, and the high surface loss potential of the chosen fungicide. These observations suggest that reduced infiltration and increased runoff and erosion from the exposed, water-slaked soil surface of orchards treated with residual preemergence herbicides may increase the potential for off-site movement of agrichemicals in surface water (Glenn and Welker, 1989; Haria et al., 1994; Merwin et al., 1994).

Both of our field tests also suggest that with sufficient rainfall or irrigation, pesticides and nitrates may run off the soil surface or leach through the soil profile with minimal interaction or retention on the soil matrix. Certain herbicide GMSs may exacerbate these bypass processes in moderately sloped upland orchards on highly structured fine textured soils. In recent years, other researchers modeling or monitoring agrichemical movement under conventional and conservation tillage have also reported major subsurface fluxes through preferential pathways, and large effluxes of agrichemicals from field drainage lines under agronomic crops (Andreini and Steenhuis, 1990; Bush et al., 1991; Harris et al., 1994; Jabro et al., 1993; Jury and Fluhler, 1992; Steenhuis et al., 1994a, 1994b). Non-saturated soil macropores, cracks, earthworm and rodent burrows, and old root channels are more likely to provide pathways for agrichemical movement in perennial crop systems where these soil structural features can develop during successive years with little disturbance of the soil profile. As leaching and runoff simulation models are tested and adapted to account more adequately for nonpoint pollution sources in agriculture, it may be important to consider the influence of different soil and weed management systems upon the movement of agrichemicals in orchard soils. Multi-year field-scale monitoring of agrichemical movement is expensive, time-consuming, and likely to produce highly variable data because of stochastic site and climate factors and the heterogeneity of many agricultural soils. However, more field experiments monitoring the fluxes and fates of agrichemicals in perennial crop systems could help identify GMSs that minimize off-farm movement of fertilizers and pesticides. 


\section{Literature Cited}

Andreini, M.S. and T.S. Steenhuis. 1990. Preferential paths of flow under conventional and conservation tillage. Geoderma 46:85-102.

Bush, P.B., W.L. Nutter, D.G. Geary, and J.W. Taylor. 1991. Pesticide movement from southern pine seed orchards: Use of CREAMS model to facilitate evaluation of off-site pesticide movement. Proc. CREAMS/ GLEAMS Symp. Publ. 4, Univ. Georgia, Coastal Expt. Sta. Tifton, Ga. p. 209-220.

Canter, L.W. 1987. Nitrates and pesticides in groundwater: An analysis of a computer-based literature search, p. 53-79. In: D.M. Fairchild (ed.). Groundwater quality and agricultural practices. Lewis Publ. Mich.

Carsel, R.F., C.N. Smith, L.A. Mulkey, J.D. Dean, and P. Jowise. 1984. User's manual for the pesticide root zone model (PRZM). release 1.EPA 600/3-84-109. U.S. EPA, Athens, Ga.

Cline, M.G. and R.L. Marshall. 1977. Soils of New York landscapes. Cornell Univ. Coop. Ext. Bul. no. 119. Ithaca, N.Y., 60 p.

Close, M.E. 1993. Assessment of pesticide contamination of groundwater in New Zealand. 2. Results of groundwater sampling. N.Z. J. Marine Freshwater Res. 27:267-273.

Flury, M. and H. Fluhler. 1995. Tracer characteristics of brilliant blue FCF. Soil Sci. Soc. Amer. J. 59:22-27.

Flury, M., H. Fluhler, W.A. Jury, and J. Leuenberger. 1994. Susceptibility of soils to preferential flow of water: A field study. Amer. Geophys. Union. Water Resources Res. 30(7):1945-1954.

Ghodrati, M. and W.A. Jury. 1990. A field study using dyes to characterize preferential flow of water. Soil Sci. Soc. Amer. J. 54:1558-1563.

Glenn, D.M. and W.V. Welker. 1989. Orchard soil management systems influence rainfall infiltration. J. Amer. Soc. Hort. Sci. 114:10-14.

Greweling, T. and M. Peech. 1965. Chemical soil tests. Cornell Univ. Agr. Expt. Sta., Ithaca, N.Y., Bul. no. 960.

Haria, A.H., A.C. Johnson, J.P. Bell, and C.H. Batchelor. 1994. Water movement and isoproturon behavior in a drained heavy clay soil. 1 . Preferential flow processes. J. Hydrol. 163:203-216.

Harris, G.L., P.H. Nicholls, S.W. Bailey, K.R. House, and D.J. Mason. 1994. Factors influencing the loss of pesticides in drainage from a cracking clay soil. J. Hydrol. 159:235-253.

Haynes, R.J. 1981. Effects of soil management practices on soil physical properties, earthworm population, and tree root distribution in a commercial orchard. Soil Tillage Res. 1:269-280.

Hogue, E.J. and G.H. Neilsen. 1987. Orchard floor vegetation management, p. 377-430. In: Horticultural Reviews, vol. 9. J. Janick (ed.). AVI Publ., Westport, Conn.

Hutson, J.L. and R.J. Wagenet. 1992. LEACHM: Leaching estimation and chemistry model, version 3. Dept. of Soil, Crop and Atmospheric Sciences Res. Ser. no. 92-93, Cornell Univ., Ithaca, N.Y., 117 p.

Jabro, J.D., J.M Jemison, Jr., L.L. Lengnick, R.H. Fox, and D.D. Friton. 1993. Field validation and comparison of LEACHM and NCSWAP. Trans. Amer. Soc. Agr. Eng. 36:1651-1657.

Jenkins, J.J., M.J. Zabik, R. Kon, and E.D. Goodman. 1983. A model for Azinphosmethyl attenuation and movement in a Michigan orchard ecosystem: 1. Development and presentation of the experimental data base. Arch. Environ. Contam. Toxicol. 12:99-110.

Jury, W.A., and H. Fluhler. 1992. Transport of chemicals through soil: Mechanisms, models, and field applications, p. 141-201. In: D.L. Sparks (ed.). Adv. Agron. no. 47.

Kotcon, J.B. and M. Wimmer. 1993. Monitoring movement of fenamiphos through soil water in peach orchards using quantitation by gas-chromatography-mass spectrometry. Bul. Environ. Contam. Toxicol. 50:3542.

Klonsky, K., F. G. Zalom, and W. Barnett. 1990. California's almond IPM program. Calif. Agr. 44:21-24.

Knisel, W.G. 1980. CREAMS: A field-scale model for chemicals, runoff, and erosion from agricultural management systems. Conservation Res. Rpt. no. 26. U.S. Dept. Agr., Wash. D.C.

Kovach, J. and J.P. Tette. 1988. A survey of the use of IPM by New York apple producers. Agr. Ecosys. Environ. 20:101-108.

Leonard, R.A., W.G. Knisel, and D.A. Still. 1987. GLEAMS: Groundwater loading effects of agricultural management systems. Trans. Amer.
Soc. Agr. Eng. 30:1403-1418.

Levanon, D., E.E. Codling, J.J. Meisinger, and J.L. Starr. 1993. Mobility of agrochemicals through soil from two tillage systems. J. Environ. Quality 22:155-161.

Logan, T.J., J.M. Davidson, J.L. Baker, and M.R. Overcash. 1987. Effects of conservation tillage on groundwater quality. Lewis Publ., Chelsea, Mich. 273 p.

Merwin, I.A., and W.C. Stiles. 1994. Orchard groundcover management impacts on apple tree growth and productivity, and soil nutrient availability and uptake. J. Amer. Soc. Hort. Sci. 119:209-215.

Merwin, I.A., W.C. Stiles, and H.M. van Es. 1994. Orchard groundcover management impacts on soil physical properties. J. Amer. Soc. Hort. Sci. 119:216-222.

N.R.C. 1989. Alternative agriculture. Natl. Acad. Press, Wash., D.C.

Nutter, W.L., W.G. Knisel, Jr., P.B. Bush, and J.W. Taylor. 1993. Use of GLEAMS to predict insecticide losses from pine seed orchards. Environ. Toxicol. Chem. 12:441-452.

Official Technological Assessment. 1990. Beneath the bottom line: Agricultural approaches to reduce agrichemical contamination of groundwater. Off. Technol. Assessment Publ. no. OTA-F-417, Wash. D.C. 79 p.

Petrovic, A.M. 1990. The fate of nitrogenous fertilizer applied to turfgrass. J. Environ. Quality 19:1-14.

Richard, T.L. and T.S. Steenhuis. 1988. Tile drain sampling of preferential flow on a field scale. J. Contam. Hydrol. 3:307-325.

Smith, W.N., S.O. Prasher, and S.F. Barrington. 1991. Evaluation of PRZM and LEACHMP on intact soil columns. Trans. Amer. Soc. Agr. Eng. 34:2413-2420.

Steenhuis, T.S., S. Pacenka, and K.S. Porter. 1987. MOUSE: A management model for evaluating groundwater contamination from diffuse surface sources aided by computer graphics. Appl. Agr. Res. 2:277-289.

Steenhuis, T.S., W. Staubitz, M.S. Andreini, J. Surface, T.L. Richard, R. Paulsen, N.B. Pickering, J.R. Hagerman, and L.D. Goehring. 1990. Preferential movement of pesticides and tracers in agricultural soils. J. Irr. Drainage Eng. 116: 50-66.

Steenhuis, T.S., S. Rice, J. Boll, I.A. Merwin, and J. Selker. 1992. Solute samplers for the vadose zone. (Abstr.) Proc. Amer. Geophys. Union, San Francisco.

Steenhuis, T.S., C.J. Ritsema, L.W. Dekker, and J.-Y. Parlange. 1994a. Fast and early appearance of solutes in groundwater by rapid and farreaching flows. Trans. 15th Intl. World Congr. Soil Sci. p. 184-203.

Steenhuis, T.S., J. Boll, G. Shalit, J.S. Selker, and I.A. Merwin. 1994b. A simple equation for predicting preferential flow solute concentrations. J. Environ. Quality 23:1058-1064.

U.S. Department of Agriculture. 1992. Agricultural chemical usage: 1991 fruits and nuts summary. U.S. Dept. Agr., Natl. Agr. Stat. Serv. Agr. Ch. 1(92). Wash., D.C.

Vendrell, P.F. and J. Zupancic. 1990. Determination of soil nitrate by transnitration of salicylic acid. Commun. Soil Sci. Plant Ann. 21:17051713.

Veneman, P.L.M., J.R. Murray, and J.H. Baker. 1983. Spatial distribution of pesticide residues in a former apple orchard. J. Environ. Quality 12:101-104.

Wauchope, R.D. 1978. The pesticide content of surface water draining from agricultural lands-A review. J. Environ. Quality 7:459-472.

Wauchope, R.D., T.M. Buttler, A.G. Hornsby, P.W.M. Augustin-Beckers, and J.P. Burt. 1992. The SCS/ARS/CES pesticide properties database for environmental decision-making. Rev. Environ. Contam. Toxicol. 123:1-13.

Weaver, J.E., H.W. Hogmire, and J.L. Brooks. 1990a. Survey for pesticides in wells associated with apple and peach orchards in West Virginia. Bul. Environ. Contam. Toxicol. 44:81-86.

Weaver, J.E., H.W. Hogmire, J.L. Brooks, and J.C. Sencindiver. 1990b. Assessment of pesticide residues in surface and soil water from a commercial apple orchard. Appl. Agr. Res. 5:37-43.

Weinbaum, S.A., R.S. Johnson, and T.M. DeJong. 1992. Causes and consequences of overfertilization in orchards. HortTechnology 2:1122125 . 